\title{
Entre mistério divino e humano: cinquenta anos de pesquisa teológica na PUC-Rio
}

\author{
Between divine and human Mystery: \\ fifty years of theological research in PUC-Rio
}

Abimar Oliveira de Moraes

\section{Resumo}

O artigo pretende esboçar rapidamente um balanço formal e sintético, destacando as linhas características do movimento das ideias que tem norteado a pesquisa teológica da PUC-Rio, analisando, em especial, o impacto desse movimento no labor teológico produzido ao longo dessas cinco décadas. Inicia por situar a pesquisa teológica da PUC-Rio dentro de um contexto de "virada antropológica" que afetou toda a teologia cristã nos últimos tempos. Em seguida, apresenta as linhas estruturais e alguns traços epistemológicos de tal teologia, concluindo que a principal missão da teologia produzida na PUCRio é pensar a fé cristã em diálogo com as transformações culturais em ato no decorrer desses cinquenta anos.

Palavras-chave: Teologia. Epistemologia teológica. Área 44 da Capes. PUC-Rio.

\section{Abstract}

The article intends to quickly sketch a formal and synthetic balance, highlighting the characteristic lines of the movement of ideas that has guided the theological research of PUC-Rio, analyzing, in particular, the impact of this movement on the theological work produced during these five decades. It begins by situating PUC-Rio's theological research within the context of an "anthropological turn" that has affected all Christian Theology in recent 
times. It then presents the structural lines and some epistemological features of such a theology, concluding that the main mission of theology produced at PUC-Rio is to think of the Christian faith in dialogue with the cultural transformations in action during these fifty years.

Keywords: Theology. Theological epistemology. Capes Area 44. PUC-Rio.

\section{Introdução}

A recente autonomia da Área Ciências da Religião e Teologia (Área 44) no sistema de avaliação da Coordenação de Aperfeiçoamento de Pessoal de Nível Superior (Capes), fez com que o debate epistemológico já existente, se tornasse uma tarefa ainda mais importante para teólogos e cientistas da religião de todo o país. ${ }^{1}$ Nesse debate, faz-se mister a escuta e a compreensão de como os próprios Programas de Pós-graduação, que compõem a Área 44, se enxergam. Um papel importante, nesse sentido, terá a investigação daqueles que foram os Programas pioneiros. Nesse quadro, portanto, encontra-se a teologia da PUC-Rio que, em 2018, completou cinquenta anos de existência e de produção de conhecimento no cenário nacional e internacional.

O presente artigo não tem a pretensão de fazer uma crônica, um inventário das teses e dissertações, dos livros e artigos científicos que ao longo desses cinquenta anos de pesquisa teológica foram produzidos por docentes, pesquisadores(as) e discentes da Pontifícia Universidade Católica do Rio de Janeiro (PUC-Rio), pois certamente esqueceria de apresentar muitos personagens, dados, temas e outros aspectos relevantes. ${ }^{2}$

Desde 2004, estamos na PUC-Rio na qualidade de docente, em especial, de 2007 até 2018, exercemos a função de coordenador de Pós-graduação. Temos o limite de não termos conhecido todos os personagens históricos que iniciaram essa empreitada, mas, ao mesmo tempo, o exercício de tal

\footnotetext{
${ }^{1}$ A título ilustrativo de tal debate, no último decênio podemos mencionar: CRUZ, E. R.; DE MORI, G., Teologia e Ciências da Religião; FERREIRA, A. C.; SENRA, F., Tendência interdisciplinar das Ciências da Religião no Brasil, p. 249-269; PASSOS, J. D.; USARSKI, F. (Orgs.), Compêndio de Ciência da Religião; SENA DA SILVEIRA, E. (Org.), Como estudar as Religiões. ${ }^{2}$ Um trabalho dessa natureza foi feito, em 2013, por ocasião das comemorações dos 45 anos de ereção do Departamento de Teologia: TEPEDINO, A. M. (Org.), Memória, Identidade, Missão.
} 
função administrativa dá-nos a possibilidade de partilhar nossa percepção da caminhada, na certeza, é óbvio, de que, embora qualificada, seja somente a nossa percepção.

O que pretendemos é esboçar rapidamente um balanço formal e sintético, destacando as linhas características do movimento das ideias que têm norteado a pesquisa teológica desde o século passado, analisando, em especial, o impacto desse movimento no labor teológico produzido pela PUC-Rio.

Iniciaremos por situar a pesquisa teológica da PUC-Rio dentro de um movimento de "virada antropológica" que afetou toda a teologia cristã nos últimos tempos. Em seguida, serão apresentadas as linhas estruturais e alguns traços epistemológicos de tal teologia. Por fim, o repensar a fé cristã em diálogo com a mudança de época será apresentado como principal missão da teologia da PUC-Rio, no decorrer desses cinquenta anos.

\section{A "virada antropológica" em Teologia}

Hoje a pesquisa científica se expande por mil e um canais e os cientistas se reconhecem responsáveis por uma orientação da opinião e da vida humana, nas suas mais variadas dimensões e/ou expressões. Esse fenômeno atinge igualmente a Teologia. ${ }^{3}$

O movimento da reflexão teológica atual está marcado, em seu conjunto, pela transferência da atenção do mero em si das realidades divinas à relação que elas têm com as afirmações e os problemas que dizem respeito à vida humana.

Se ao longo de séculos a investigação teológica se interessou quase unicamente pelo tema de Deus, a reflexão atual leva em conta aquilo que os seres humanos estão descobrindo sobre si e sobre as demais realidades, num movimento de crescente atenção à pessoa humana e seus contextos vitais.

\footnotetext{
${ }^{3}$ Refletindo sobre a Teologia frente às exigências da ciência, Karl Rahner, assim se expressa: "o teólogo pode e deve a priori convencer-se que o diálogo com a ciência modifica também a fisionomia própria, historicamente condicionada, da teologia, e que podemos exigir que esse diálogo seja absolutamente aberto. Portanto, [...] a teologia pode e deve redizer-se, [...] ela não tem o direito de ser pretensiosa, [...] ela não é a mais alta depositária de todo conhecimento humano, de tal forma que todas as outras ciências devessem ser consideradas como órgãos de execução de um sistema de pensamento totalitário do qual o governo supremo e adequado lhe pertencesse. De saída, a teologia deve saber (e isto precisamente em virtude de seus próprios princípios) que existe um inelutável pluralismo no conhecimento humano" (RAHNER, K., Teologia e ciência, p. 40-41).
} 
A pesquisa teológica, justamente por se interessar pelo tema de Deus, vem se debruçando sobre um outro tema correlato: o da pessoa humana. Fundando-se, muito mais, no sentido que as afirmações sobre Deus possam ter para o iluminar da vida humana. Todo conhecimento de Deus passa pela via de elaboração do conhecimento humano, não podendo haver conhecimento de Deus, sem mútuo, profundo e, até mesmo, prévio conhecimento do humano.

Marcada pela antropologia, a teologia atual quer-se mais em ligação com as questões humanas e seu processo de construção de relações públicas e sociais. ${ }^{4}$ Esse fazer (ou refazer) teológico marcado pelas questões humanas, chamamos de "virada antropológica". ${ }^{5}$ Em tal "virada" o que aconteceu foi o constatar que, depois de uma ampla elaboração teológica que assegura bases teóricas relevantes (o que chamamos em Teologia de pesquisa dogmática), era preciso proceder a uma larga abertura para a vida humana como verdadeiro e importante espaço de construção do pensar teológico.

O Concílio Vaticano II foi celebrado dentro desse espírito e, por essa razão, procurou dar respostas e orientações para as pessoas humanas. Em especial, através da Gaudium et spes, os padres conciliares colocaram a criatura humana no centro das atenções pastorais e teológicas ao afirmarem: "não se encontra nada verdadeiramente humano que não lhes [discípulos de Cristo] ressoem no coração". ${ }^{6}$ Ou ainda: "na realidade o mistério do homem só se torna claro verdadeiramente no mistério do Verbo encarnado". ${ }^{7}$ Assim a igreja (e sua teologia) deseja que todo o gênero humano conheça a chave

\footnotetext{
4 "A teologia é benéfica à sociedade assim como esta última é idealizada no Ocidente. Ela funciona como uma espécie de ombudsman humanitário. A teologia não é um empecilho à ciência - embora muitas vezes seja um problema. O empecilho serão as sociedades sem teologia, isto é, aquelas que não admitem críticas internas a suas convicções" (LIGORIO SOARES, A. M., Teologia na Universidade, como convém, p. 288).

${ }^{5}$ Não é pequeno o número de pesquisadores que participaram desse movimento de nova colocação do humano no debate teológico, pela natureza desse trabalho, aqui é suficiente destacar a contribuição de Karl Rahner que, não poucas vezes, debruçou-se sobre a questão em muitos momentos de sua produção teológica. Em seu clássico Curso Fundamental da Fé, por exemplo, da primeira até a quarta seção, toda sua sistematização teológica parte do humano para chegar ao divino (RAHNER, K., Curso Fundamental da Fé, p. 37-170). Além do Curso, ver: A antropologia: problema teológico; Est-il possible aujourd'hui de croire?; L'homme a l'ecoute du Verbe; O Homem e a Graça. Para uma síntese das principais ideias antropológicas que norteiam o pensamento de Rahner: VOLGRIMLER, H., Karl Rahner, p. 211-247.

${ }^{6} \mathrm{GS} 1$.

${ }^{7}$ GS 22.
} 
que ela tem para a solução de seus problemas: Jesus Cristo e seu plano de salvação. ${ }^{8}$

Esse procedimento de atenção à vida humana trouxe consigo o interrogativo: mas afinal, o que é a salvação? Um pulular de definições apareceu. Nelas, o que é constante é a preocupação em evidenciar a existência de uma relação entre comunhão definitiva com Deus e as antecipações históricas de tal comunhão na vida humana. Segundo França Miranda:

A salvação do ser humano deve apresentar realizações históricas que a comprovem, que signifiquem plenificação das diversas dimensões humanas e, consequentemente, libertação dos males que o afligem. Contudo, tais males dependem das situações concretas em que ele se encontra, com suas correspondentes leituras soteriológicas. Assim podemos distinguir salvação em plenitude (Deus) de suas realizações históricas. Consequentemente, não nos deve surpreender que as tematizações da salvação cristã sejam múltiplas e diferenciadas ao longo da história do cristianismo. ${ }^{9}$

Portanto, sem deixar de se debruçar sobre o tema da comunhão definitiva com Deus, a teologia atual quer investigar sobre as multíplices dimensões da existência humana. Essas multíplices dimensões representam momentos que estão sempre ligados, de algum modo, ao da comunhão definitiva.

Por isso, a teologia reflete sobre a libertação de todas as formas de

\begin{abstract}
${ }^{8} \mathrm{Na}$ última sessão do Concílio, Paulo VI assim se expressa: "na verdade, a Igreja, reunida em Concílio, entendeu sobretudo fazer a consideração sobre si mesma e sobre a relação que a une a Deus; e também sobre o homem, o homem tal qual ele se mostra realmente no nosso tempo: o homem que vive; o homem que se esforça por cuidar só de si; o homem que não só se julga digno de ser como que o centro dos outros, mas também não se envergonha de afirmar que é o princípio e a razão de ser de tudo. Todo o homem fenomênico — para usarmos o termo moderno - revestido dos seus inúmeros hábitos, com os quais se revelou e se apresentou diante dos Padres conciliares, que são também homens, todos Pastores e irmãos, e por isso atentos e cheios de amor; o homem que lamenta corajosamente os seus próprios dramas; o homem que não só no passado mas também agora julga os outros inferiores, e, por isso, é frágil e falso, egoísta e feroz; o homem que vive descontente de si mesmo, que ri e chora; o homem versátil, sempre pronto a representar; o homem rígido, que cultiva apenas a realidade científica; o homem que como tal pensa, ama, trabalha, sempre espera alguma coisa, à semelhança do 'filius accrescens'; o homem sagrado pela inocência da sua infância, pelo mistério da sua pobreza, pela piedade da sua dor; o homem individualista, dum lado, e o homem social, do outro; o homem 'laudator temporis acti', e o homem que sonha com o futuro; o homem por um lado sujeito a faltas, e por outro adornado de santos costumes" (PAULO VI, PP., Discurso na última sessão pública do Concílio Vaticano II).
\end{abstract}

${ }^{9}$ FRANÇA MIRANDA, M., A salvação de Jesus Cristo, p. 22. 
alienação e de opressão impostas à vida humana e que impedem que, cada pessoa humana, torne-se construtora e responsável pelo seu próprio destino. A comunhão com Deus no arco da experiência histórica e a sua completude definitiva são atingidas, até mesmo, nos mais ínfimos níveis de libertação pessoal e social.

Isso faz com que a reflexão teológica passe a interrogar a história e o contexto histórico, entendendo, sempre mais, que a realização do projeto de Deus dá-se na história e para a plena realização dos seres humanos. Essa atenção da teologia à dimensão histórica não é outra coisa que fidelidade ao princípio de que a história é o lugar do diálogo entre o divino e o humano e, consequentemente, o lugar onde a construção do pensar teológico se faz. Ela é o lugar onde Deus se revela e, ao mesmo tempo, lugar onde o ser humano é convidado a acolhê-Lo.

Nesse sentido, são interessantes as palavras de Edward Schillebeeckx:

Deus trava relações pessoais com o homem no seio da história humana [...], só esta história da salvação nos permite entrever a verdadeira fisionomia do Deus Trindade. [...] Desta maneira, ele (Deus) entabula com seu povo, como parceiro, um diálogo existencial em que nos entrega sua vida íntima. [...] A história da salvação [...] é que nos revela que Deus propriamente é, e o que ele realmente quer ser para os homens. [...] A revelação é um acontecimento salvífico em que, sob forma visível e terrestre, uma realidade salvífica divina atinge a realidade humana. A revelação [...] é, mais fundamentalmente, a própria realização histórica de uma iniciativa salvífica divina e trans-histórica no interior da estrutura da história humana. ${ }^{10}$

Nessas palavras, é possível perceber como a revelação volta a ser entendida "como relação pessoal, comunicativa de Deus à humanidade". ${ }^{11} \mathrm{O}$ principal acento recai sobre a dimensão experiencial, dinâmica e histórica. Como já mencionado, procura-se antes a significação do mistério de Deus para a pessoa humana de hoje.

A expressão "mistério de Deus" (e suas variantes) passa a ser, como no corpus paulino e na época patrística, novamente entendida como plano divino da salvação que Deus manifesta ao ser humano, ao longo das diversas etapas da sua história até a conclusão dessa mesma história.

\footnotetext{
${ }^{10}$ SCHILLEBEECKX, E., Revelação e teologia, p. 337-339.

${ }^{11}$ LIBÂNIO, J. B., Teologia da Revelação a partir da Modernidade, p. 158.
} 
Nessa perspectiva, a teologia atual se apresenta como discurso científico de alguém que crê que Deus se auto-comunica salvificamente na história humana e, ao mesmo tempo, como conjunto de perguntas de um sujeito humano que crê a partir da sua situação no tempo e no espaço.

Tal reflexão dirige-se, quer a um interlocutor que crê (aqui a teologia apresenta-se como explicitação da fé), quer a um interlocutor que não crê. Nesse segundo caso, a teologia procura mostrar que a revelação, como de fato se deu (e não numa possibilidade abstrata), pode responder à estrutura antropológica humana mais profunda.

Partindo daquilo que está, muitas vezes, implícito ao ser humano, para mostrar-lhe como a revelação pode plenificar, explicitar, realizar essa sua dimensão existencial transcendental. Aqui a teologia apresenta-se fundamentalmente como discurso plausível ou razoável da fé. ${ }^{12}$

\section{Linhas estruturais da pesquisa teológica produzida na PUC-Rio}

O projeto, que dá surgimento à PUC-Rio, está ancorado nessas raízes teológicas, apenas mencionadas. Em seu "Marco Referencial", lemos que ela "se empenha, de modo especial, no cultivo dos valores humanos e da ética cristã e afirma o primado da pessoa sobre as coisas", ${ }^{13}$ reconhecendo-se "como um espaço onde possa ser realizado o diálogo entre o conhecimento da razão humana e a fé cristã". ${ }^{14}$

A mesma opção pela pessoa humana que caracteriza a teologia em sua "virada antropológica" é a base que caracteriza a PUC-Rio desde sua origem e que a fez construir um caminho de colaboração na construção de um saber interdisciplinar e dialógico possibilitando, assim, "a discussão da unidade e do sentido do conhecimento intelectual e científico, e do significado da existência humana". ${ }^{15}$

Carneiro de Andrade testemunha:

No início da década de 1960, constitui-se no Brasil um forte movimento que propugnava uma ampla reforma no sistema universitário brasileiro,

\footnotetext{
${ }^{12}$ Para Pié-Ninot, a teologia "tiene como identidade fundar y justificar la pretensión de verdade de la Revelación cristiana como propuesta sensata de credibilidad, y poder así 'dar razón de la esperanza' (cf. 1Pe 3,15)": PIÉ-NINOT, S., La Teología Fundamental, p. 75.

${ }^{13}$ PONTIFÍCIA UNIVERSIDADE CATÓLICA DO RIO DE JANEIRO, Marco Referencial, n. 4. ${ }^{14}$ PONTIFÍCIA UNIVERSIDADE CATÓLICA DO RIO DE JANEIRO, Marco Referencial, n. 4. ${ }^{15}$ PONTIFÍCIA UNIVERSIDADE CATÓLICA DO RIO DE JANEIRO, Marco Referencial, n. 5.
} 
visando, de um lado, a transformar as Universidades em centros de produção de conhecimento científico e humanista e, de outro, sua expansão inclusiva. Esse movimento resultou na reforma universitária de $1968 .^{16}$

Nesse mesmo ano de 1968, o Departamento de Teologia foi erigido e integrado ao recém-criado Centro de Teologia e Ciências Humanas (CTCH) da PUC-Rio. Em 1972, foi criado o Programa de Pós-graduação (mestrado e doutorado) reconhecido pela Santa Sé por meio da Sagrada Congregação para a Educação Católica. Em 1977, a Capes, que possuía função de indução, supervisão e fomento do sistema, inicia um processo de sistematização de avaliação de Programas. A PUC-Rio enviou os dados da Teologia que recebe, nos dois primeiros anos a qualificação "SC" (sem conceito). Tal conceituação corresponde ao tempo inicial de atividades do Programa até a realização das primeiras defesas. Já em 1979, a Teologia recebe o conceito "A", maior de então, indicando o reconhecimento da excelência das atividades de pesquisa e produção de conhecimento teológico. ${ }^{17}$

Quando, em 1995, a Capes passa por uma reestruturação e fortalece-se como instituição responsável pelo acompanhamento e avaliação dos cursos de Pós-graduação stricto sensu já existentes no Brasil, ${ }^{18}$ dentre os mais de mil cursos de mestrado e dos seiscentos de doutorado, permanecem os cursos de doutorado e mestrado em Teologia da PUC-Rio. Tal acompanhamento e avaliação realizados pela Capes são formalizados em 29 de novembro de 1995, através da portaria 1.461, publicada no Diário Oficial de 11 de dezembro do mesmo ano.

O Programa fazia parte da Área Filosofia/Teologia, tendo sempre sido avaliado nos estratos de excelência. Em 1996, tanto o doutorado como o mestrado receberam o conceito A. ${ }^{19}$ Em 1998, momento em que houve a estratificação através de conceitos numéricos, o Programa obteve conceito seis (6), nota máxima atribuída à Área, naquele momento. Em todas as avaliações do período de 2001 a 2016, o Programa obteve conceito cinco (5).

Em 2016, a Área Ciências da Religião e Teologia foi criada pela Portaria

\footnotetext{
${ }^{16}$ CARNEIRO DE ANDRADE, P. F., Os 45 anos do Departamento de Teologia da PUC-Rio, p. 21.

${ }^{17}$ CARNEIRO DE ANDRADE, P. F., O reconhecimento da Teologia como saber universitário, p. 27-28.

${ }^{18}$ CAPES, História e missão.

${ }^{19}$ CARNEIRO DE ANDRADE, P. F., Os 45 anos do Departamento de Teologia da PUC-Rio, p. 22.
} 
Capes 174/2016, publicada no Diário Oficial da União de 13 de outubro do mesmo ano, ${ }^{20}$ tendo participado da última avaliação quadrienal, junto com outros vinte (20) Programas, sendo dezoito (18) deles acadêmicos. Ao final do quadriênio 2013-2016, o Programa foi avaliado pela Capes com conceito quatro (4).

Ao longo desses anos, o Programa, perseguindo o aprimoramento de sua proposta, manteve sua estruturação em duas áreas de concentração - Teologia Bíblica e Teologia Sistemático-Pastoral - por entender, através da apreciação dos processos de avaliação da Capes, que sua estrutura curricular está consolidada e faz com que o Programa tenha um papel destacado no cenário teológico acadêmico nacional e internacional. ${ }^{21}$

As pesquisas em teologia da PUC-Rio encontram-se impulsionadas por dois grandes eixos: a) volta às fontes; e b) atenção às inquietações do presente. Isso permite-nos afirmar que toda teologia construída na PUC-Rio vem sendo influenciada pelo que está "antes" dela e pelo que está "diante" dela.

São muitas as pesquisas marcadas pelo recurso às fontes bíblicas. ${ }^{22}$ Através da exegese, cujo objetivo é aproximar-se o máximo possível do sentido exato do texto sagrado em vista de sua atualização, nossas pesquisas vêm buscando sistematizar o dado bíblico, através de estudos de aspectos parciais que marcam as principais etapas da história do diálogo entre o divino e o humano, sem, contudo, deixar de considerar a Escritura em sua totalidade, onde esse diálogo divino-humano desenrola-se e atualiza-se progressivamente na história e exprime-se na sucessão, unidade e diversidade dos livros bíblicos.

O ponto de partida desse trabalho de investigação é o texto bíblico inserido em seu contexto histórico, cultural e religioso, que inclui o contato com as culturas circunstantes. A atenção a esse recurso fez com que a pesquisa da área bíblica reconhecesse que a análise metodológica dos textos é base e eixo de toda sua construção. Por isso, as pesquisas bíblicas na PUC-Rio têm uma grande preocupação com o aspecto metodológico. Com essa finalidade, a teologia da PUC-Rio valorizou e valoriza o estudo das línguas bíblicas,

\footnotetext{
${ }^{20}$ A Capes denomina, em 2016, a Área 44 de Teologia. Após solicitação formal dos vinte um (21) Programas que a compunham, naquele momento, a designação passou a ser Ciências da Religião e Teologia, a partir da resolução n. 1/2017.

${ }^{21}$ Até a conclusão desse artigo o Programa de Pós-graduação da PUC-Rio tinha levado à defesa 191 teses e 358 dissertações.

${ }^{22}$ Um rico inventário da maior parte dessas produções científicas pode ser encontrado em: CORRÊA LIMA, M. L., A Identidade do Departamento de Teologia na Área de Teologia Bíblica, p. 91-102.
} 
culminando, inclusive, no exigir proficiência em grego e hebraico bíblicos para seus pós-graduandos.

As pesquisas que se concentram na área bíblica investigam os textos bíblicos, seu ambiente histórico, social e cultural, seguindo o desenvolvimento da pesquisa metodológica das ciências bíblicas, estudando os textos de ambos os Testamentos, com interface da literatura extrabíblica, mas também intencionando aplicar e avaliar os diversos métodos exegéticos e as novas abordagens hermenêuticas. ${ }^{23}$

Ao mesmo tempo, a teologia da PUC-Rio está solicitada diretamente pelas questões atuais que interessam à pessoa humana e a envolvem. Tais questões não podem ser consideradas como resolvidas somente por formulações de fé, necessárias, mas vinculadas a outros momentos histórico-culturais. A pesquisa teológica, portanto, visa aprofundar a relação da fé também com o momento presente. Essa é a força motriz da área denominada sistemático-pastoral na PUC-Rio.

A esse respeito são interessantes as palavras de Garcia Rubio:

Voltando ao futuro da Teologia da PUC-Rio, parece claro que é chamada a continuar aprofundando o desafio desse mundo moderno/pós-moderno, procurando respostas iluminadas pela fé cristã. Diálogo crítico, dando prioridade à realidade da nossa cidade, do Brasil e da América Latina [...]. Este diálogo crítico está se tornando cada vez mais necessário e urgente, embora deva ser reconhecido que se trata de um diálogo difícil [...]. Reconhecer que há diferentes modos de conhecer a realidade, cada um com seu método próprio, é um passo indispensável para tornar possível o diálogo entre os distintos saberes. ${ }^{24}$

O ponto de partida desse trabalho de diálogo e investigação é a relação entre as afirmações positivas e consolidadas da teologia e as diversas realidades humanas que as interrogam. A investigação teológica nessa área de concentração percebe a fé como portadora de um conteúdo atual mas que não é possível de expressar-se fora das culturas humanas, pois o objeto da interpelação divina é o ser humano em sua história concreta.

Por essa razão, a investigação da área sistemático-pastoral, trabalhando com metodologias bibliográficas e de pesquisa de campo, entende o ser

${ }^{23}$ Para um panorama da Linha e Projetos de pesquisa da Área Teologia Bíblica ver: DEPARTAMENTO DE TEOLOGIA DA PUC-RIO, Área de Concentração Teologia Bíblica.

${ }^{24}$ GARCIA RUBIO, A., Orientações da Teologia, p. 43 e 47. 
humano como ser sociocultural, com suas muitas interpelações à configuração (ou reconfiguração) religiosa e eclesial de nossos dias e, ao mesmo tempo, em sua dimensão pessoal integral, bem como no dinamismo de construção de uma espiritualidade encarnada e transformadora. ${ }^{25}$

Os valores da modernidade e da cultura humana são largamente reconhecidos e reintegrados na investigação teológica, nessa área. Não como retratação daquilo que outrora não se soube valorizar no que tange à cultura humana, mas sim, por reconhecimento de que a teologia precisa exercer uma função transformadora tanto fora como dentro da experiência de fé ${ }^{26}$

\section{Traços epistemológicos da pesquisa teológica da PUC-Rio}

A PUC-Rio, em seu pioneirismo, teve a importante missão de colaborar com a afirmação, no cenário acadêmico nacional, da cientificidade da teologia. Tal cenário estava marcado pelo distanciamento entre Estado e igrejas, que originou a ideia de que a produção teológica deveria estar circunscrita ao espaço eclesiástico e não público. ${ }^{27}$

Nesse artigo não nos é possível revisitar e reavaliar todos os aspectos relevantes dessa problemática. O que se propõe é mais modesto e diz respeito, somente, a destacar alguns traços basilares do estatuto epistemológico da teologia produzida pela PUC-Rio. Entendemos que a atenção a esses traços possa contribuir no processo de compreensão do desenvolvimento epistemológico não somente da pesquisa teológica realizada na PUC-Rio, como também de uma boa parte da investigação hoje desenvolvida na atual Área Ciências da Religião e Teologia da Capes.

A investigação teológica da PUC-Rio tomou como ponto de partida três pressupostos que assim sintetizamos: a) a teologia, por sua origem e natureza,

${ }^{25}$ Para um panorama da Linhas e Projetos de pesquisa da Área Teologia Sistemático-Pastoral ver: DEPARTAMENTO DE TEOLOGIA DA PUC-RIO, Área de Concentração Teologia Sistemático-Pastoral.

${ }^{26}$ Sobre alguns aspectos da investigação na Área Teologia Sistemático-Pastoral ver: TEPEDINO, A. M., Uma identidade dinâmica, p. 77-86; BINGEMER, M. C., Departamento de Teologia: espaço e missão, p. 107-120.

27 "Sobretudo para a comunidade científica, a teologia é vista como uma falsa ciência, relegada à condição estrita de religiosidade (coisas de foro íntimo) ou de religião (coisas das Igrejas) e, portanto, sem lugar na academia. No caso brasileiro, o fato torna-se ainda mais nítido, uma vez que somente em 1999 a teologia foi reconhecida legalmente como curso superior. A universidade brasileira foi instituída e consolidada sem a presença da teologia” (PASSOS, J. D., Teologia e outros saberes, p. 34). 
não se enquadrava, necessariamente, no modelo de ciência que naquele determinado momento histórico vigorava no sistema educativo universitário brasileiro e que estava vigente em outras áreas de investigação; b) a teologia podia se propor como ciência no espaço acadêmico nacional porque possuía objeto próprio, método (ou métodos), unidade e sistematização; e c) entre teologia e demais ciências era possível estabelecer uma relação de correlação. ${ }^{28}$

Ao mesmo tempo que se originava e se consolidava o Departamento de Teologia da PUC-Rio, a academia brasileira viu surgir e passou a familiarizarse com um novo conceito de ciência que pode ser caracterizado por três pontos de vistas: antropológico, teórico e sociocultural.

Do ponto de vista antropológico, dentre outros aspectos, esse novo conceito de ciência exige, como padrão demonstrativo de cientificidade, que o pesquisador(a) demonstre neutralidade, abertura para eventuais críticas e intersubjetividade.

Do ponto de vista teórico, passa a ser tido como científico no Brasil, tudo o que se apresente como um sistema dedutivo e condicional de afirmações hipotéticas, estruturado segundo as regras das deduções lógicas, baseado, porém, em experiências que possam ser verificadas por outras pessoas. $\mathrm{O}$ saber científico passa a estar fundado não somente sobre a verificação empírica, mas também, sobre a justificação lógica, fazendo com que a validade desse saber possa também ser de natureza hipotética.

Do ponto de vista sociocultural, a ciência passa a ser entendida como um âmbito cultural autônomo e fortemente diversificado, como expressão de tantas pesquisas que são conduzidas simultaneamente, em solo nacional, como interação com outras importantes instituições sociais brasileiras (indústria, comércio, defesa, mobilidade, saúde, turismo, dentre outras), como totalidade de tantas áreas e possibilidades de investigação que originam gradualmente diversas disciplinas autônomas, mas coligadas entre si que têm em comum uma estrutura formal, mas não um princípio material.

Esse amplo cenário de desenvolvimento da ciência no Brasil faz com que a teologia da PUC-Rio avance em suas relações interdisciplinares. Ao longo desses cinquenta anos, olhando para a pesquisa teológica docente

\footnotetext{
${ }^{28}$ Em 1968, o teólogo canadense René Latourelle, professor na Gregoriana de Roma, apresentava uma obra, traduzida em 1971 no Brasil, que apresentava traços de cientificidade para a teologia muito próximos do fazer teológico da PUC-Rio: "designa hoje pelo têrmo de ciência tôda disciplina que se beneficia de um objeto e método próprios e que termina numa síntese comunicável” (LATOURELLE, R., Teologia, ciência da salvação, p. 52).
} 
e discente da PUC-Rio, é possível distinguir dois aspectos que subsistem e sustentam tais relações interdisciplinares: a) de um lado, é possível identificar relações internas entre a teologia e as outras ciências; e b) de outro, é possível identificar relações externas vigentes entre a teologia e as outras ciências.

Quanto às relações internas com as demais ciências, a pesquisa teológica na PUC-Rio realizou uma "opção fundamental" de voltar sua atenção às fontes primeiras do cristianismo. Ao fazer isso, deparou-se com uma experiência cristã que, embora entendida como profundamente distinta dos demais saberes, sempre sublinhou a importância da razão humana e das ciências que o humano é capaz de produzir para formular a resposta que é convidado a dar à revelação divina.

Tal produção teológica promovida pela PUC-Rio não foi assumida somente como um gesto de condescendência verso um mundo fortemente marcado pelo valor da razão humana, mas como consequência teológica de uma visão explicitamente cristã do mundo. Ao prestar cada vez maior atenção às fontes da fé cristã, a pesquisa teológica da PUC-Rio constrói-se sob a base da íntima correlação entre criação e encarnação, natureza e graça, cultura e fé, modernidade e religião, humanidade e cristianismo, razão e crença, diálogo humano e divino.

É óbvio que, em tal contexto, correlação não significa indiferença entre uma realidade e outra, mas sim, uma relação elementar, integral e positiva feita de disposição e dependência mútua entre as duas realidades envolvidas. Nesse sentido, em sua produção teológica, a PUC-Rio vem esmerando-se em assegurar como a criação esteja orientada verso a encarnação, recebendo dessa última seu sentido pleno, mas, ao mesmo tempo, inversamente a encarnação pressupõe a criação e tem como tarefa decifrá-la e aperfeiçoá-la.

Daí emergem investigações teológicas análogas baseadas sobre os binômios fé e cultura, religião e modernidade que visam oferecer uma visão cristã do mundo na qual a razão humana é orientada verso o diálogo com a "razão divina", ao mesmo tempo em que a "razão divina" só deve ser necessariamente entendida como relacional e sustentadora da razão humana que atua no tempo e na história.

A primeira consequência dessas atenções às relações internas faz com que a pesquisa bíblica na PUC-Rio considere a Sagrada Escritura como "texto humano-divino", isto é, onde é possível perceber um estreito liame entre o conhecimento da fé e da razão. No texto sagrado, existe 
uma profunda e inseparável unidade entre conhecimento racional e conhecimento de fé. ${ }^{29}$

A segunda consequência faz com que a pesquisa sistemático-pastoral na PUC-Rio se defina como reflexão sistemática e metodológica sobre a fé cristã feita por aqueles que creem e como articulação científica sobre o conteúdo crido e a experiência do crer.

Quanto às relações externas com as demais ciências, a pesquisa teológica na PUC-Rio está ancorada no conceito de que a teologia tem por objeto o mistério divino, transmitido pelas tradições orais e escritas da comunidade cristã, enquanto pode ser conhecido mediante uma atividade da razão. A investigação teológica na PUC-Rio tem, portanto, duas partes integrantes: uma positiva e outra especulativa, definidas como o estado científico teológico respectivamente do auditus e do intellectus fidei. Essas duas partes estão organicamente unidas e se aperfeiçoam continuamente. ${ }^{30}$

${ }^{29}$ Pode nos ajudar a compreender essas relações internas, a título ilustrativo, a afirmação feita por Maria de Lourdes Corrêa Lima, em conclusão a um estudo sobre as relações entre História e Teologia: "se não se pode interpretar a Escritura a partir da perspectiva de busca de um concordismo entre texto e ciência histórica, tampouco exegese e ciência histórica se encontram necessariamente em contraste. A justa medida parece encontrar-se na delimitação do método e da competência de cada uma e da integração entre as duas no respeito às suas peculiaridades. A finalidade da exegese exige que a ciência histórica lhe seja complementar e auxiliar - e não princípio hermenêutico. A finalidade da ciência histórica - caso ela se interesse pelo antigo Israel ou pelo Cristianismo primitivo - exige que os textos bíblicos, embora carregados de condicionamentos históricos, sejam considerados dentro da finalidade segundo a qual foram escritos (religiosa, não científica). Tal delimitação não cria necessariamente uma dicotomia, uma vez que não parte de uma contraposição, mas é condição de possibilidade, ao mesmo tempo que demarcação de competências, para o aprofundamento seja da exegese seja da ciência histórica no âmbito das sociedades que estão por trás da Escritura" (CORRÊA LIMA, M. L., História e Teologia, p. 110). Tal perspectiva exegética é marca característica da pesquisa de docentes, discentes e egressos da PUC-Rio.

${ }^{30}$ Por vezes, a relação entre auditus e intellectus se encontra articulada na sinergia entre pesquisas de Linhas diferentes, como por exemplo, no diálogo bíblico-litúrgico entre Waldecir Gonzaga e Luiz Fernando Ribeiro Santana: GONZAGA, W., Ap 19,1-8: profetismo na Liturgia, p. 566-585; RIBEIRO SANTANA, L. F., O hino aleluático de Ap 19,1-7 e a celebração da Liturgia das Horas, p. 586-604. Em outras, os dois momentos guiam o todo da investigação de um pesquisador, como demonstram as palavras introdutórias de André Luiz Rodrigues da Silva: "nosso principal objetivo nas seguintes páginas percorre, de uma forma bem concreta, o caminho proposto pelo Santo Padre, o papa Francisco, enquanto esse indicava aos estudiosos, em sua despedida do Brasil em virtude da Jornada Mundial da Juventude, a necessidade de compreender a falta de uma especificação mais teológica sobre a importância da mulher na comunidade cristã, reconhecendo ser "necessária uma profunda teologia da mulher". Desta feita, a isso se conjuga a nossa proposta na tentativa de avançar sobre o assunto com o auxílio da reflexão que São Justino elaborou nos seus escritos, reve- 
Por essa razão, para desenvolver sua tarefa investigativa, a pesquisa teológica da PUC-Rio, há cinquenta anos, se constrói em diálogo com uma pluralidade de disciplinas e suas temáticas, citamos alguns exemplos: filosofia, filologia, história, ciências da religião, psicologia, medicina, economia, ciências políticas, pedagogia, sociologia, direito, comunicação social, arte, língua, literatura, antropologia, dentre tantas outras.

É importante sublinhar que a teologia da PUC-Rio, ao utilizar os dados dessas disciplinas e temáticas, foi se consolidando e desenvolvendo novas perspectivas, pois sempre considera seus dados como autênticos e autônomos ${ }^{31}$. Alicerçada num conceito de ciência mais elástico e compreensivo, tem construído um saber teológico científico articulando de maneira indissociável experiência de fé e razão.

Por isso, a investigação teológica na PUC-Rio caracteriza-se, sobretudo, como reflexão sobre um "dado", isto é, "o dado revelado" que exige a organização de uma pesquisa de tipo positivo integral, onde a teologia é entendida como uma ciência que reconhece que o lugar da dedução ou especulação teológica situa-se dentro de um processo que é primeiramente indutivo, não sendo, portanto, possível a elaboração da "inteligência da fé", sem antes nos dedicarmos à "escuta da fé" dentro do contexto que a modernidade hoje nos apresenta.

\section{Pensar a fé cristã no atual contexto de mudança de época: a missão teológica da PUC-Rio}

Estamos numa mudança de época onde o pluralismo, a secularização, a laicização, a democratização da vida contemporânea-dentre outros fenômenos - trouxeram importantes questionamentos para a experiência cristã. A teologia da PUC-Rio não tardou em reconhecer que dados dessa natureza, e tantos

\footnotetext{
lando uma combinação de temas que ainda não tinham sido valorizados por estudos precedentes. Em virtude desta combinação e da avaliação propostas por nós, estaremos chamando de "articulação" o nexo interpretativo dos elementos que representam os mais expressivos temas que envolvem a mulher na literatura justineia" (RODRIGUES DA SILVA, A. L., A visão de São Justino sobre a mulher, p. 530).

${ }^{31}$ A GS 36 apresenta dois tipos de compreensão da expressão "autonomia das realidades terrestres”. Seguindo a indicação do Concílio Vaticano II, todo o projeto da PUC-Rio, incluída sua teologia, entendeu que as sociedades e as ciências gozam de leis e valores próprios que devem ser conhecidos, usados e ordenados. Reconhecendo os métodos próprios de cada ciência, a teologia da PUC-Rio nunca entendeu as demais ciências como opostas à fé.
} 
outros concomitantes, reclamam uma nova justificativa e recolocação da fé cristã nas sociedades hodiernas. ${ }^{32}$

Nessa mudança, estamos assistindo à passagem de uma situação na qual a fé cristã dominava o conjunto dos setores da vida pessoal e social a uma situação onde grande número de indivíduos e coletivos torna-se independente dela. Tal fenômeno retorna constantemente nas reflexões teológicas de docentes, discentes e egressos da PUC-Rio. Em tais reflexões, tal passagem ou mudança epocal é vista em modo positivo, como processo que certifica a existência de um claro fenômeno cultural: mundo e realidade humana tendem a emancipar-se e desfazer certos "laços da fé".

Por isso, a teologia da PUC-Rio sentiu-se na obrigação de enfrentar com decisão esse fato incontroverso, esforçando-se por investigar o significado desse processo de mudança e produzindo uma imagem onde o Deus cristão ${ }^{33} \mathrm{e}$ os temas relativos à sua autocomunicação são apresentados como mistério que envolve gratuita e misericordiosamente a pessoa humana e que torna possível um autêntico processo de humanização. ${ }^{34}$

Dito em outros termos, as transformações em curso tornaram-se "temática obrigatória" na produção teológica da PUC-Rio, fazendo com que tal produção

\footnotetext{
32 "No atual momento da história ocidental da humanidade e, em nosso caso, na América Latina, a crescente separação entre os valores do Evangelho e as referências maiores das culturas se manifesta [sic] tanto nos fatos em si quanto nos critérios de enfrentamento. No caso dos fatos ou desafios, como pensar em uma sociedade ou cultura em rica articulação com o Evangelho quando a vida se encontra ameaçada nas mais diversas instâncias? No caso dos critérios, como pensar em compreender toda a realidade a partir de Jesus Cristo, quando tantas possibilidades culturais e religiosas se apresentam?" (PORTELLA AMADO, J., Mudança de época e conversão pastoral, p. 305).

${ }^{33}$ Por exemplo, encerrando um comentário exegético de Mc 6,34, o Prof. Heitor Carlos Santos Utrini propõe a identidade de Jesus, em chave de compaixão: "a seção culmina com a confissão de fé de Pedro, que se desdobra nos anúncios da paixão. Dessa forma, Jesus é, com efeito, o Messias esperado, porém, tal messianismo se concretiza na aceitação voluntária do sofrimento. Sua identidade será plenamente revelada no momento de sua cruz e ressurreição. Ora, se Jesus é o Cristo que se revela na cruz, é justamente por causa de sua compaixão que ele assume o destino do Filho do Homem e aceita a morte de cruz. Daí a necessidade de tal caracterização messiânica, pois a compaixão o levará à cruz, e só assim será possível a compreensão, da parte do homem, acerca de sua identidade" (SANTOS UTRINI, H. C., "E teve compaixão deles (Mc 6,34)", p. 159).

34 “A espiritualidade - 'vida inteira guiada pelo Espírito Santo' - é sempre humanizadora de todas as dimensões do humano e integradora de todas as suas relações. A espiritualidade não é encontro com o imaterial - esta seria uma forma mais grega do que bíblica de pensar! Espiritualidade entendida como vida segundo o Espírito é o encontro com um furacão, é abertura a uma força irresistível de vida, à própria vida de Cristo! Por isso, é uma forma de estar no mundo" (PEDROSA DE PÁDUA, L. Espiritualidade e Bíblia, p. 72-73).
} 
não buscasse resistir a elas, lutar contra elas e nem combatê-las, por causa dos seus problemas, mas o que ocorreu foi a sua assunção a partir duma compreensão de que o Cristianismo em sua origem assumiu a postura dialogal, ${ }^{35}$ de que o caminho indicado pelo Concílio Vaticano II é o da construção de um paradigma teológico novo ${ }^{36} \mathrm{e}$ de que os autênticos diálogos acontecem a partir de dentro.

Assim, alguns problemas centrais dos tempos atuais foram sendo assumidos pela investigação teológica da PUC-Rio, desencadeando um processo de reexame do processo de análise e interpretação do dado bíblico, do nexo entre religião e modernidade e da relação entre fé e cultura. ${ }^{37} \mathrm{~A}$ pesquisa teológica da PUC-Rio debruçou-se sobre problemas fundamentais, na tentativa da produzir atitudes dialógicas a partir da fé cristã em diálogo com o atual contexto sócio-cultural.

A teologia da PUC-Rio vem buscando evidenciar como, a partir do crer cristão, é possível identificar e promover experiências comuns aos homens e mulheres de hoje que geram valores e o empenho em lutas comuns pelos direitos humanos, pela igualdade, pelo bem comum da paz, ${ }^{38}$ pela justiça, pela tolerância, pelo cuidado com a "casa comum", ${ }^{39}$ pela superação dos conflitos,${ }^{40}$ dentre outras. Com isso, sua teologia enveredou na direção da autotransformação da experiência da fé cristã, não no sentido de relativizá-la, mas no sentido de transformar aquilo que nela não é mais capaz de garantir um futuro de plausibilidade do ato de crer.

Assim, podemos dizer que a reflexão da PUC-Rio vem apresentando a preocupação de evitar o risco de uma autocompreensão anti-moderna do cristianismo. A ideia geral que guia a reflexão da PUC-Rio é que o cristianismo e a cultura atual podem estabelecer um diálogo. Em suas pesquisas, portanto, a teologia não considera a cultura atual como anti-cristã ou pós-cristã, mas busca, superando dicotomias e dualismos, postular uma "nova aliança" entre a fé cristã e cultura hodierna. A teologia tem, assim, um importante papel de favorecimento do diálogo produtivo, sem abandonar a criticidade da razão, nem obrigar a fé cristã à dissolução de sua identidade particular.

\footnotetext{
${ }^{35}$ COSTA, P. C., Diálogo entre Cristianismo e mundo cultural nos primeiros séculos, p. 313-331.

${ }^{36}$ QUEIROZ RONSI, F., O Concílio Vaticano II e o diálogo inter-religioso, p. 153-167.

${ }^{37}$ Tal processo de reexame norteia as três Linhas de Pesquisa do Programa de Pós-graduação: DEPARTAMENTO DE TEOLOGIA DA PUC-RIO, Áreas de Concentração.

${ }^{38}$ TEPEDINO, A. M., Paz: dom messiânico e bem comum, p. 185-196.

${ }^{39}$ AGOSTINI FERNANDES, L., Teologia, Antropologia e Ecologia em Gn 1,1-2,4a, p. 27-46.; RIBEIRO CIRNE, L. F., O Espaço da Biodiversidade, p. 66-84.

${ }^{40}$ CORRÊA LIMA, L., O conflito entre Israel e Palestina, p.197-209.
} 
Uma das marcas predominantes da teologia da PUC-Rio é a superação do dilema ao qual foi conduzido o ato de crer na sociedade contemporânea. Dilema no qual, de um lado, a fé cristã, tal como foi até aqui pensada e vivida, é considerada disfuncional e, portanto, está sofrendo um lógico declínio; e, por outro lado, decretar sua decadência pode ter graves consequências sobre a integração normativa da sociedade. ${ }^{41}$

Pensar a relação entre o mundo em mudança e o credo cristão, passa, na teologia da PUC-Rio, por dois processos convergentes: a) o reconhecimento e a promoção dos valores dos tempos atuais; e b) a construção de uma relação dialógica centrada sobre uma antropologia integral e sobre os direitos que derivam da dignidade desse ser humano integral. ${ }^{42}$ Desses dois processos derivam três princípios fundamentais: a) ninguém deve ser obrigado a professar a fé cristã, mas a liberdade de professá-la deve ser tutelada, incluindo, naturalmente, a liberdade de não crer; b) deve existir igualdade entre as pessoas embora exista diversidade religiosa, assim, nenhuma visão ou ponto de vista, religioso ou não, pode gozar de status privilegiado; e c) cada grupo e/ou comunidade deve ser ouvido e incluído num processo permanente de determinação dos rumos concretos da sociedade atual.

Tais princípios fundamentais devem ser tutelados como direito e dever de todos os membros da sociedade. Por essa razão, a teologia da PUCRio entende que a fé cristã, com sua particular concepção, é desafiada a enfrentar a questão de Deus e a sua fé n'Ele levando em conta os diversos aspectos que compõe a cultura atual. ${ }^{43} \mathrm{E}$, ao mesmo tempo, entende que o que crê deve ser visto como interlocutor social que toma Deus como sua referência.

\footnotetext{
${ }^{41}$ SOUZA, W., “O Princípio responsabilidade” em Hans Jonas, p. 172-191.

${ }_{42}$ "Para a Revelação, o indivíduo é sujeito diante de si mesmo e diante das relações com a exterioridade. [...] A Revelação indica um ser humano concebido a partir de uma base de relações, onde o individual, o social, o afetivo, o familiar, o ético, o confortante, o compromissal e todas as demais dimensões humanas são valorizadas por igual, ainda que temporariamente recebam maior incidência que as outras" (PORTELLA AMADO, J., Realmente livre?, p. 43).

${ }^{43}$ Segundo Ruini: "afirmou-se no Ocidente, não só entre as pessoas de cultura, mas mesmo também entre as pessoas comuns, a convicção de um 'florescer do homem', isto é, de um ideal de plenitude de vida que seria possível sem Deus. É este hoje, para a fé, um desafio decisivo, um desafio claramente não só intelectual, mas espiritual, moral, existencial, ao qual se pode responder não se limitando a criticar a sensibilidade atual e a colocar em evidência seus indubitáveis limites, mas haurindo da riqueza da proposta cristã sobre Deus e sobre o homem, para oferecer a esta sensibilidade uma possibilidade de realização muito mais plena e muito maior" (RUINI, C., Deus, referência absoluta na mudança da cultura, p. 213).
} 
Outro elemento integrante desse processo de reflexão é a construção de uma relação dialógica sobre a base do reconhecimento do pluralismo ${ }^{44}$ e que obriga a teologia da PUC-Rio a debruçar-se sobre os temas da solidariedade e da responsabilidade verso o outro, em especial os mais frágeis. ${ }^{45}$ A investigação teológica da PUC-Rio se constrói dentro de um cenário social que exige um alto grau de participação e de empenho, um cenário de emergência do sujeito onde cada indivíduo é convidado a um processo de identificação com a sua comunidade e colaboração para a construção de uma sociedade mais justa e pacífica. ${ }^{46}$ Por essa razão, a dimensão socio-transformadora tornou-se muito importante para a construção da teologia da PUC-Rio.

Para a investigação teológica da PUC-Rio, os cristãos e cristãs, em especial o laicato, devem se apresentar significativamente como agentes de transformação social no mundo atual e, contemporaneamente, se sintam cidadãos responsáveis pela construção do estado democrático. ${ }^{47}$ Consequentemente, a pesquisa teológica da PUC-Rio interessa-se pela revisão de algumas questões urgentes que dizem respeito à prática evangelizadora/

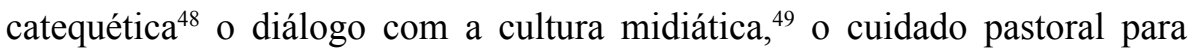
com as famílias, ${ }^{50}$ a existência da opinião pública, do consenso e do dissenso eclesial e do "estilo sinodal" na organização das comunidades eclesiais. ${ }^{51}$

Em seu fazer cinquentenário, não sem tensões, a teologia da PUC-Rio

${ }^{44}$ MESQUIATI DE OLIVEIRA, D., Notas sobre pluralismo, diálogo inter-religioso e missão, p. 307-337.

${ }^{45}$ CRUZ PEREIRA, S., O legado da "Igreja dos pobres" para a Igreja na América Latina, p. 22-37; FREITAS CARDOSO, M. T., No sentido da vida, p. 315-334.

${ }^{46}$ TURKSON, P., Elementos constitutivos para uma sociedade mais justa e pacífica, p. 17-38.

47 "A Igreja que saiu, juntamente com toda a humanidade, de duas grandes guerras e que sabe que a pobreza e a miséria têm ganhado terreno no mundo [...] não pode dar outra resposta senão aquela de ajudar e colaborar para o bem comum em vista da erradicação da fome e da miséria, da ignorância e da injustiça social etc., e sempre em colaboração com todos" (GONZAGA, W., Amor de Deus e do próximo, p. 25).

48 “A catequese deve fazer muito mais do que afirmar que Deus quer a salvação do gênero humano. Ela deve ser sinal eficaz desta salvação. Em outras palavras, se apresenta não como aquela que diz que Deus salva, mas como o sinal em atos da própria salvação de Deus: uma ação catequética que não se separa da diaconia" (MORAES, A., A catequese hoje, p. 274). Ver, também: MORAES, A.; CALANDRO, E., A Iniciação à Vida Cristã a partir de Aparecida, p. 1-21.

${ }^{49}$ MORAES, A., Cultura midiática e religião, p. 103-112.

${ }^{50}$ MORAES, A., Desafios e perspectivas à Pastoral Familiar a partir de Amoris Laetitia, p. 580-598.

${ }^{51}$ CATELAN FERREIRA, A. L., A sinodalidade eclesial no magistério do Papa Francisco, p. $390-404$. 
vem tentando responder ao difícil interrogativo: é possível configurar um modelo de democracia e de Estado laico em diálogo com uma forma de profissão pública da fé cristã? A esse interrogativo, a pesquisa teológica da PUC-Rio vem buscando dar uma resposta positiva através da proposição de uma forma de profissão de fé ético-profética capaz de se distender na "esfera pública da sociedade civil" com iniciativas de transformação social, críticas das estruturas e das ações totalitárias e absolutistas.

Para a teologia da PUC-Rio é de capital importância que a fé cristã seja capaz de assumir seu papel público convalidando a separação, a interdependência e a colaboração entre igreja e sociedade, respeitando a lógica argumentativa que substitui as conviç̧ões absolutistas no âmbito sociopolítico e exige a tradução do credo cristão em categorias capazes de construir o tecido social.

De outro lado, a pesquisa teológica da PUC-Rio sustenta que o sistema sociopolítico não deve ignorar as contribuições que os grupos religiosos podem aportar ao processo democrático. A identidade coletiva de sociedade exige sempre a interação política entre as partes religiosas e não religiosas da população, desde que se reconheçam uma e outra como membros dessa mesma sociedade. Exige o reconhecimento da profissão de fé como forma de expressão de valores, experiências e anseios humanos que devem integrar-se como parte preciosa do esforço da humanidade em conferir sentido à sua vida.

Em outras palavras, a teologia da PUC-Rio tem se deixado guiar pela tentativa de apresentar novas bases para o humanismo diante de uma sociedade que transcura a necessidade e a importância de crer. Um crer que confira sentido à vida no mundo contemporâneo e que faça surgir uma práxis que permita a "superação da contingência", abrindo uma estrada que possa ser percorrida pela esperança de que existe algo mais importante que a própria vida.

Guiado pela dimensão pastoral e espiritual, o fazer teológico da PUC-Rio busca ajudar a pessoa humana a tomar em consideração a plausibilidade do ato de crer, não somente demonstrando racionalmente os seus fundamentos, mas mostrando a força vinculante e transformadora do mesmo em suas precisas experiências concretas. ${ }^{52}$

Assim, a pesquisa teológica da PUC-Rio vem desenvolvendo os temas da experiência de fé, pastoral e mística como espaço de afirmação da dignidade e dos valores humanos, entendendo que a fé cristã se encontra dentro de

\footnotetext{
${ }^{52}$ Nessa direção vão as pesquisas sobre espiritualidade e mística desenvolvidas pela Profa. Lúcia Pedrosa de Pádua e Profa. Maria Clara Bingemer. Ver, por exemplo: PEDROSA DE PÁDUA, L., Espiritualidade integradora.
} 
uma dinâmica generativa de humanização que promove as experiências de autotranscendência humanas. Experiências nas quais a pessoa humana transcende a si mesma, no sentido de ser conduzida, pelo próprio Deus, além dos confins do seu próprio ser e agir, por estar fascinada por Alguém que está além de si mesma.

Por essa razão, há um largo interesse em pesquisar tais experiências de fé, pastorais e místicas que produzem um movimento que "afasta" a pessoa humana de si e a atrai e projeta na direção de algo (o reinado de Deus) que está além dos nossos confins: interação solidária com outros seres humanos, o cuidado com a natureza, o amor à humanidade, as dores e angústias modernas, o mistério da vida e da morte, a comunhão e diálogo com Deus, são alguns dos temas importantes do fazer teológico da PUC-Rio.

Experiências similares comportam uma forte carga de atração gerando um sentido de vida, todas elas têm em comum o "de-centrar" do sujeito humano já que, nas experiências de autotranscendência, cada pessoa humana percebe seus próprios limites e, portanto, o sentido de dependência e de gratuidade, isto é, de que há uma experiência de um dom recebido, isto é, não devido, mas mesmo assim ofertado pelo Deus de Jesus Cristo. Identificando tais experiências, a teologia da PUC-Rio busca interpretá-las a partir da fé cristã, situando-as, assim, dentro de um plano de salvação divino (mistério) que sustenta a vida e convida à pessoa humana à transcendência. Tal função hermenêutica teológica realizada na PUC-Rio tem como base o dado moderno da liberdade humana, isto é, assim como o crente não pode constringir o não crente a aceitar sua interpretação religiosa, assim o não-crente não pode sustentar que a sua interpretação não-religiosa seja a única racionalmente defensável. Nesse sentido, uma das funções da teologia será produzir uma hermenêutica acerca da plausibilidade do ato de crer.

As experiências de autotranscendência pertencem ao nosso ser humano. Mais do que pura e simples necessidade funcional, elas fazem parte de uma necessidade que diz respeito à qualidade e ao sentido da vida. Em sua teologia, a PUC-Rio, por essa razão, as qualifica como simbólicas, litúrgicas e sacramentais, situando-as no âmbito da criatividade humana. Assim as experiências de autotranscendência alargam as opções humanas, potencializando - e não limitando - o sujeito humano, conduzindo-o para além de si, para além dos seus confins biológicos, psíquicos e sociais, conduzindo-o a uma fecunda e produtiva ação de produção simbólico, litúrgico e sacramental que tem como fundamento a sacramentalidade do Verbo Divino Encarnado. 
A observação feita por Ribeiro Santana ilustra bem essa perspectiva antropológico-simbólico-litúrgico-sacramental da PUC-Rio:

É de nosso interesse considerar a "dimensão litúrgica" da vida cristã, já que a revelação neotestamentária aplica - na quase totalidade de seu uso - leitourgía à experiência cotidiana vivida pelos cristãos, peregrinos neste mundo. Para tal servir-nos-emos de dois modelos bíblicos [...]. A razão de ser da escolha [...] é o fato de em ambos os modelos ser clara a temática da vida cristã, em sua totalidade, como um ato de culto a ser prestado a Deus. ${ }^{53}$

Em tais atividades criativas, a vida humana se descobre como uma realidade aberta, incompleta e provisória, sempre dependente de projetos "em caminho". Falando da missão da esperança, Kuzma diz:

A missão da esperança é motivada pelo movimento de Deus em nosso favor, revelando-nos o seu futuro e convidando-nos a seguir em sua direção, mas irrompe da esperança cristã vivida junto à comunidade de fé e da sociedade em que se encontra. [...] As situações presentes na atual sociedade latino-americana e, também, no mundo como um todo, ainda não perderam de vista o seu caráter emergencial, que suscitam em nós (e em todos) um olhar preferencial em favor dos pobres, dos excluídos, dos marginalizados, das mulheres, das crianças, dos doentes, dos abandonados e dos que não têm voz nem vez na sociedade. ${ }^{54}$

Vemos assim como a realização existencial humana se desenvolve num espaço e num tempo. Por essa razão, a teologia da PUC-Rio se interessa por um ser humano radicalmente histórico, solidário com seu passado e suas tradições, mas num momento presente que deve ser preenchido pelo futuro de Deus, que o convida a concretizar e atuar um projeto de vida autenticamente humano aqui e agora, na certeza e na espera do último projeto divino.

\section{Conclusão}

Observando suas origens e avaliando o processo de consolidação e desenvolvimento vivido ao longo desses cinquenta anos, é possível afirmar

${ }^{53}$ RIBEIRO SANTANA, L. F., Liturgia no Espírito, p. 184-185.

${ }^{54}$ KUZMA, C., O futuro de Deus, p. 52. 
que a teologia da PUC-Rio prestou um autêntico serviço às relações entre fé e cultura, religião e modernidade, no cenário nacional. Esmerou-se em garantir sua cientificidade, ainda que nunca tenha se entendido como ciência no sentido experimental do termo. Ao optar a ter por horizonte a busca da verdade última que a fé cristã confessa como o Verbo de Deus feito humano, a teologia da PUC-Rio toma como ponto de partida um princípio crível para algumas pessoas, mas que jamais é evidente para ninguém, exigindo, portanto, constante busca e reinterrogação do autêntico modo do crer cristão.

Em vários dos seus aspectos, a teologia produzida na PUC-Rio se fundamenta sobre aspectos conhecidos e verificáveis por todos, mesmos os que optam por não crer. Um dado fundamental em sua reflexão é que a fé cristã é uma experiência de encarnação e, portanto, existem nela aspectos que podem e devem ser explorados e explicados por pesquisas que não necessariamente comungam dessa fé. Daí a necessidade da adoção de métodos e conteúdos que segundo o objeto de estudo são independentes da crença.

Querendo refletir cientificamente sobre o escopo da revelação de Deus para a pessoa humana, a teologia na PUC-Rio recorreu e recorre às contribuições que as demais ciências podem oferecer no desenvolvimento dessa sua tarefa primeira. Ao mesmo tempo, contribui, principalmente com as ciências humanas, na tentativa de formulação de conclusões humanamente satisfatórias a certas interrogações basilares da pessoa humana. Nesse sentido, a noção de correlação permitiu que ela se integrasse com os demais Departamentos que compõem o Centro de Teologia e Ciências Humanas (CTCH) da PUC-Rio. ${ }^{55}$

Ao produzir uma teologia centrada no ser humano e na sua aventura histórico-salvífica, a investigação teológica da PUC-Rio renovou-se em sua fonte e em seus prolongamentos. Em sua fonte, especialmente, na área bíblica; e em seus prolongamentos, especialmente, na área sistemático-pastoral.

Forçoso é confessar que, nesse tocante, a teologia da PUC-Rio tateia ainda no período dos ensaios. Por essa razão, não esteve e não estará isenta de tensões várias em muitos temas. Flutuações de pensamento, riscos de erros, são consequências necessárias de uma teologia que, ao longo de cinquenta

\footnotetext{
${ }^{55}$ Atualmente os Departamentos que compõe o CTCH são: Arquitetura e Urbanismo, Artes e Design, Educação, Filosofia, Letra, Psicologia e Teologia. A missão do CTCH, inspirada na tradição humanístico-cristã, é promover a cultura em seus diversos planos e definições, formar profissionais competentes e comprometidos com a ética, o bem social e a sustentabilidade ambiental, e respeitar todas as formas de expressão das diversidades.
} 
anos, se quer em diálogo com a cultura humana; fazem parte duma teologia sujeita às condições da história humana. Contudo, cremos que, em muitos temas, a PUC-Rio vem dando, com competência, e, por vezes, pioneirismo, sua contribuição para as soluções teológicas de hoje e amanhã.

De maneira conclusiva, vale ressaltar que a investigação teológica da PUC-Rio é realizada tanto por clérigos como por leigas e leigos, tanto por cristãos de expressões eclesiais históricas como por cristãos dos novos movimentos eclesiais, num processo dialógico interno e externo à fé cristã. ${ }^{56}$ A todos e todas é dado justa liberdade de investigação e de fazer conhecer sua maneira de ver, no domínio de sua competência. ${ }^{57}$ De fato, a história atesta que sempre houve lugar para uma grande diversidade de teologias e de teólogos e teólogas. Além de benéfica para a própria ciência teológica, essa diversidade é fonte de progresso científico.

O presente artigo tentou salientar alguns traços que julgou característicos da pesquisa teológica na PUC-Rio. Ao fazer isso, damo-nos conta que construímos tanto uma retrospectiva quanto uma prospectiva, uma vez que tais traços estão em função de um movimento que toda a ciência teológica precisa ainda continuar realizando.

Que esses sejam traços tanto do nosso passado recente, bem como de nosso futuro próximo. Muito já fizemos, mas nos encontramos ainda com muito por fazer, em nosso cuidado em sermos um serviço ao diálogo entre Deus e a pessoa humana. Nessa tarefa, guie-nos as recentes palavras do Papa Francisco:

Ensinar e estudar teologia significa [...] se encontrar com as necessidades das pessoas às quais é anunciado de maneira compreensível e significativa. Devemos evitar uma teologia que [...] olha para a humanidade de um castelo de vidro. É aprendida para ser vivida: teologia e santidade são

\footnotetext{
${ }^{56}$ O Departamento de Teologia da PUC-Rio tem longa história de acolhida e diálogo ecumênico. O ecumenismo e o diálogo inter-religioso tornaram-se, inclusive, objeto de investigação do Prof. Jesús Hortal e, mais recentemente, da Profa. Maria Teresa de Freitas Cardoso. FREITAS CARDOSO, M. T., Ter em vista o ser humano, p. 137-150; HORTAL, J., A salvação dos judeus, p. 294-306.

${ }^{57} \mathrm{O}$ augúrio de GS 62 encontrou um significativo eco no Departamento de Teologia da PUC-Rio: "é de desejar que muitos leigos consigam uma conveniente formação nas ciências sagradas e não poucos, entre eles, havendo oportunidade, dediquem-se ex-professo a estes estudos e os aprofundem. Para que consigam desempenhar o seu dever, seja reconhecida aos fiéis, clérigos e leigos, a justa liberdade de exprimir as suas idéias com humildade e firmeza, nos assuntos de sua competência".
} 
um binômio inseparável. [...] A teologia que elaborais [...] acompanhe também os processos culturais e sociais, em particular as transições difíceis. Neste tempo a teologia deve enfrentar também os conflitos: não só os que experimentamos na Igreja, mas também os relativos ao mundo inteiro e que são vividos pelas ruas da América Latina. [...] A teologia seja expressão de uma Igreja que é "hospital de campo", que vive a sua missão de salvação e cura no mundo. [...] O teólogo [...] seja uma pessoa capaz de construir humanidade ao seu redor, de transmitir a divina verdade cristã em dimensão deveras humana. ${ }^{58}$

\section{Referências bibliográficas}

AGOSTINI FERNANDES, L. Teologia, Antropologia e Ecologia em Gn 1,12,4a. Atualidade Teológica, v.15, n.37, p. 27-46, jan./abr. 2011. Disponível em: $\quad<$ https://www.maxwell.vrac.puc-rio.br/18914/18914.PDFXXvmi=>. Acesso em: 30 de dez. 2018.

BINGEMER, M. C. Departamento de Teologia: espaço e missão. In: TEPEDINO, A. M. (Org.). Memória, Identidade, Missão. Teologia da PUCRio - 45 anos. Rio de Janeiro: Editora PUC-Rio, 2013. p. 107-120.

CAPES. História e missão. Disponível em: <www.capes.gov.br/historia-emissao >. Acesso em: 21 jun. 2018.

CARNEIRO DE ANDRADE, P. F. O reconhecimento da Teologia como saber universitário: tensões e articulações entre as dimensões confessional e profissional. In: LIGÓRIO SOARES, A. M.; PASSOS, J. D. (Orgs). Teologia pública. Reflexões sobre uma área de conhecimento e sua cidadania acadêmica. São Paulo: Paulinas, 2011. p. 21-36.

CARNEIRO DE ANDRADE, P. F. Os 45 anos do Departamento de Teologia da PUC-Rio. In: TEPEDINO, A. M. (Org.). Memória, Identidade, Missão. Teologia da PUC-Rio - 45 anos. Rio de Janeiro: Editora PUC-Rio, 2013. p. 21-24.

CATELAN FERREIRA, A. L. A sinodalidade eclesial no magistério do Papa Francisco. Atualidade Teológica, v.22, n.59, p. 390-404, mai./ago. 2018. Disponível em: <https://www.maxwell.vrac.puc-rio.br/34480/34480. PDFXXvmi=>. Acesso em: 22 de dez. 2018.

\footnotetext{
${ }^{58}$ FRANCISCO, PP., Carta por ocasião do Centenário da Faculdade de Teologia da Pontifícia Universidade Católica Argentina.
} 
CONCÍLIO VATICANO II. Constituição Pastoral Gaudium et Spes sobre a Igreja no mundo de hoje. In: VIER, F. (Org.). Compêndio do Vaticano II. Constituições, Decretos, Declarações. Petrópolis: Vozes, 1998. p. 141-256.

CORRÊA LIMA, M. L. A Identidade do Departamento de Teologia na Área de Teologia Bíblica. In: TEPEDINO, A. M. (Org.). Memória, Identidade, Missão. Teologia da PUC-Rio - 45 anos. Rio de Janeiro: Editora PUC-Rio, 2013. p. 91-102.

CORRÊA LIMA, M. L. História e Teologia. Reflexões na perspectiva da exegese bíblica. Atualidade Teológica, v.17, n.43, p. 101-111, jan./abr. 2013. Disponível em: <https://www.maxwell.vrac.puc-rio.br/22658/22658. PDFXXvmi=>. Acesso em: 22 de dez. 2018.

CORRÊA LIMA, L. O conflito entre Israel e Palestina: o papel de tradições judaicas e cristãs. In: PORTELLA AMADO, J.; AGOSTINI FERNANDES, L. (Orgs.). Cultura da Paz num mundo em conflito. Rio de Janeiro: Editora Puc-Rio / Letra Capital, 2017. p. 197-209.

COSTA, P.C. Diálogo entre Cristianismo e mundo cultural nos primeiros séculos. Atualidade Teológica, v.13, n.33, p. 313-331, set./dez. 2009. Disponível em: $<$ https://www.maxwell.vrac.puc-rio.br/18280/18280.PDFXXvmi=>. Acesso em: 29 de dez. 2018.

CRUZ, E. R.; DE MORI, G. Teologia e Ciências da Religião: a caminho da maioridade acadêmica no Brasil. São Paulo: Paulinas, 2011.

CRUZ PEREIRA, S. O legado da "Igreja dos pobres" para a Igreja na América Latina. Pesquisas em Teologia, v.1, n.2, p. 22-37, jan./jun. 2018. Disponível em: $<$ http://periodicos.puc-rio.br/index.php/pesquisasemteologia/article/ view/682/499>. Acesso em: 2 de jan. 2019.

DEPARTAMENTO DE TEOLOGIA DA PUC-RIO. Área de Concentração Teologia Bíblica. Disponível em: <http://www.pos.teo.puc-rio.br/index.php/ areas-de-concentracao/teologia-biblica/>. Acesso em: 22 dez. 2018.

DEPARTAMENTO DE TEOLOGIA DA PUC-RIO. Área de Concentração Teologia Sistemático-Pastoral. Disponível em: $<$ http://www.pos.teo.puc-rio. br/index.php/areas-de-concentracao/teologia-sistematico-pastoral/>. Acesso em: 22 dez. 2018.

DEPARTAMENTO DE TEOLOGIADAPUC-RIO. Áreas de Concentração. 
Disponível em: <http://www.pos.teo.puc-rio.br/index.php/areas-deconcentracao/>. Acesso em: 22 dez. 2018.

FERREIRA, A. C.; SENRA, F. Tendência interdisciplinar das Ciências da Religião no Brasil: o debate epistemológico em torno da interdisciplinaridade e o paralelo com a constituição da área no país. Numen, v.15, n.2, p. 249-269, 2012.

FRANCISCO, PP. Carta por ocasião do Centenário da Faculdade de Teologia da Pontifícia Universidade Católica Argentina. Disponível em: $<$ https://www.vatican.va $>$. Acesso em: 21 jun. 2018.

FRANÇA MIRANDA, M. A salvação de Jesus Cristo. A doutrina da graça. São Paulo: Loyola, 2009.

FREITAS CARDOSO, M. T. No sentido da vida. Em diálogo sobre a prevenção do suicídio. Atualidade Teológica, v.15, n.38, p. 315-334, mai./ago. 2011. Disponível em: <https://www.maxwell.vrac.puc-rio.br/20327/20327. PDFXXvmi=>. Acesso em: 2 de jan. 2019.

FREITAS CARDOSO, M. T. Ter em vista o ser humano: a Gaudium et Spes e o diálogo ecumênico. In: AGOSTINI FERNANDES, L. (Org.). Gaudium et Spes em questão. Reflexões bíblicas, teológicas e pastorais. São Paulo: Paulinas, 2016. p. 137-150.

GARCÍA RUBIO, A. Orientações da Teologia. In: TEPEDINO, A. M. (Org.). Memória, Identidade, Missão. Teologia da PUC-Rio - 45 anos. Rio de Janeiro: Editora PUC-Rio, 2013. p. 39-53.

GONZAGA, W. Ap 19,1-8: profetismo na Liturgia. Atualidade Teológica, v.22, n.60, p. 566-585, set./dez. 2018. Disponível em: $<$ https://www.maxwell. vrac.puc-rio.br/35761/35761.PDFXXvmi=>. Acesso em: 28 de dez. 2018.

GONZAGA, W. O amor de Deus e do próximo na Gaudium et Spes 16 e 24. In: AGOSTINI FERNANDES, L. (Org.). Gaudium et Spes em questão. Reflexões bíblicas, teológicas e pastorais. São Paulo: Paulinas, 2016. p. 15-39. HORTAL, J. A salvação dos judeus: de São Paulo à declaração Nostra Aetate. Atualidade Teológica, v.20, n.53, p. 294-306, mai./ago. 2016. Disponível em: $<$ https://www.maxwell.vrac.puc-rio.br/27120/27120.PDFXXvmi=>. Acesso em: 28 de dez. 2018.

KUZMA, C. O futuro de Deus na missão da Esperança. Uma aproximação escatológica. São Paulo: Paulinas, 2014. 
LATOURELLE, R. Teologia, ciência da salvação. São Paulo: Paulinas, 1971. LIBÂNIO, J. B. Teologia da Revelação a partir da Modernidade. São Paulo: Loyola, 1992.

LIGÓRIO SOARES, A. M. Teologia na Universidade, como convém. In: LIGÓRIO SOARES, A. M.; PASSOS, J. D. (Orgs). Teologia pública. Reflexões sobre uma área de conhecimento e sua cidadania acadêmica. São Paulo: Paulinas, 2011. p. 277-289.

MESQUIATI DE OLIVEIRA, D. Notas sobre pluralismo, diálogo interreligioso e missão. Atualidade Teológica, v.20, n.53, p. 307-337, mai./ago. 2016. Disponível em: <https://www.maxwell.vrac.puc-rio.br/27122/27122. PDFXXvmi=>. Acesso em: 28 de dez. 2018.

MORAES, A. A catequese hoje: reflexões teológico-pastorais a partir da Evangelii Gaudium. In: PORTELLA AMADO, J.; AGOSTINI FERNANDES, L. (Orgs.). Evangelii Gaudium em questão. Aspectos bíblicos, teológicos e pastorais. Rio de Janeiro: Editora PUC-Rio; São Paulo: Paulinas, 2014. p. 263-276.

MORAES, A. Cultura midiática e religião. Contribuições para uma hermenêutica prospectiva. Atualidade Teológica, v.14, n.34, p. 103112, jan./abr. 2010. Disponível em: <https://www.maxwell.vrac.puc-rio. br/17669/17669.PDFXXvmi=>. Acesso em: 2 de jan. 2019.

MORAES, A. Desafios e perspectivas à Pastoral Familiar a partir de Amoris Laetitia. Atualidade Teológica, v.20, n.54, p. 580-598, set./dez. 2016. Disponível em: <https://www.maxwell.vrac.puc-rio.br/27761/27761. PDFXXvmi=>. Acesso em: 2 de jan. 2019.

MORAES, A.; CALANDRO, E. A Iniciação à Vida Cristã a partir de Aparecida: perspectivas catequéticas após o primeiro decênio da Conferência. Pesquisas em Teologia, v.1, n.1, p. 1-21, jan./jun. 2018. Disponível em: <http:// periodicos.puc-rio.br/index.php/pesquisasemteologia/article/view/749/498>. Acesso em: 2 de jan. 2019.

PASSOS, J. D.; USARSKI, F. (Orgs.). Compêndio de Ciência da Religião. São Paulo: Paulinas / Paulus, 2013.

PASSOS, J. D. Teologia e outros saberes. Uma introdução ao pensamento teológico. São Paulo: Paulinas, 2010.

PAULO VI, PP. Discurso na última sessão pública do Concílio Vaticano II em 7 de dezembro de 1965. Disponível em: http://w2.vatican.va/content/ 
paul-vi/pt/speeches/1965/documents/hf_p-vi_spe_19651207_epilogoconcilio.html>. Acesso em: 20 de dez. 2018.

PEDROSA DE PÁDUA, L. Espiritualidade e Bíblia. Integração e humanização geradas por um Livro vivo. Atualidade Teológica, v.18, n.46, p. 58-80, jan./abr. 2014. Disponível em: <https://www.maxwell.vrac.puc-rio.br/23292/23292. PDFXXvmi=>. Acesso em: 29 de dez. 2018.

PEDROSA DE PÁDUA, L. Espiritualidade integradora: o testemunho privilegiado de Santa Teresa de Ávila. In: GARCÍA RUBIO, A. (Org.). O Humano Integrado. Abordagens de Antropologia Teológica. Petrópolis: Vozes, 2007. p. 181-207.

PIÉ-NINOT, S. La Teología Fundamental. "Dar razón de la esperanza” (1Pe 3,15). Salamanca: Ediciones Secretariado Trinitario, 2001.

PONTIFÍCIA UNIVERSIDADE CATÓLICA DO RIO DE JANEIRO. Marco Referencial. Disponível em: <http://www.puc-rio.br/sobrepuc/ marcoreferencial/principal.html>. Acesso em: 18 de ago. 2018.

PORTELLA AMADO, J. Mudança de época e conversão pastoral: uma leitura das conclusões de Aparecida, Atualidade Teológica, v.12, n.30, p. 301-316, set./dez. 2008. Disponível em: <https://www.maxwell.vrac.puc-rio. br/18418/18418.PDFXXvmi=>. Acesso em: 28 de dez. 2018.

PORTELLAAMADO, J. Realmente livres? A ambiguidade antropológica dos ambientes urbanos. In: GARCÍA RUBIO, A. (Org.). O Humano Integrado. Abordagens de Antropologia Teológica. Petrópolis: Vozes, 2007. p. 23-46.

QUEIROZ RONSI, F. O Concílio Vaticano II e o diálogo inter-religioso: os avanços na busca por um novo paradigma teológico. Atualidade Teológica, v.20, n.52, p. 153-167, jan./abr. 2016. Disponível em: <https://www.maxwell. vrac.puc-rio.br/26613/26613.PDFXXvmi=>. Acesso em: 29 de dez. 2018.

RAHNER, K. A Antropologia: problema teológico. São Paulo: Herder, 1968. RAHNER, K. Curso Fundamental da Fé. Introdução ao conceito de cristianismo. São Paulo: Paulus, 2008.

RAHNER, K. Est-il possible aujourd'hui de croire? Dialogue avec les hommes de notre temps. Tours: Mame, 1966.

RAHNER, K. L'Homme a l'ecoute du Verbe. Fondements d'une philosophie de la religion. Tours: 1968. 
RAHNER, K. O Homem e a Graça. São Paulo: Paulinas, 1970.

RAHNER, K. Teologia e ciência. São Paulo: Paulinas, 1971.

RIBEIRO CIRNE, L. F. O Espaço da Biodiversidade: uma leitura teológica na perspectiva da sustentabilidade ambiental. Atualidade Teológica, v.15, n.37, p. 66-84, jan./abr. 2011. Disponível em: <https://www.maxwell.vrac.puc-rio. br/18913/18913.PDFXXvmi=>. Acesso em: 30 de dez. 2018.

RIBEIRO SANTANA, L. F. Liturgia no Espírito. O culto cristão como experiência do Espírito Santo na fé e na vida. Rio de Janeiro: Editora PUCRio; São Paulo: Editora Reflexão, 2015.

RIBEIRO SANTANA, L. F. O hino aleluático de Ap 19,1-7 e a celebração da Liturgia das Horas. Atualidade Teológica, v.22, n.60, p. 586-604, set./dez. 2018. Disponível em: <https://www.maxwell.vrac.puc-rio.br/35763/35763. PDFXXvmi=>. Acesso em: 28 de dez. 2018.

RODRIGUES DA SILVA, A. L. A visão de São Justino sobre a mulher: personagens e notícias. Atualidade Teológica, v.19, n.51, p. 529-545, set./dez. 2015. Disponível em: <https://www.maxwell.vrac.puc-rio.br/25865/25865. PDFXXvmi=>. Acesso em: 24 de dez. 2018.

RUINI, C. Deus, referência absoluta na mudança da cultura: como apresentar Deus hoje. Atualidade Teológica, v.15, n.38, p. 211-242, mai./ago. 2011. Disponível em: <https://www.maxwell.vrac.puc-rio.br/20326/20326. PDFXXvmi=>. Acesso em: 24 de dez. 2018.

SANTOS UTRINI, H. C. "E teve compaixão deles (Mc 6,34)". A novidade da caracterização de Jesus como Messias compassivo em Mc. Atualidade Teológica, v.18, n.46, p. 147-161, jan./abr. 2014. Disponível em: <https:// www.maxwell.vrac.puc-rio.br/23292/23292.PDFXXvmi=>. Acesso em: 29 de dez. 2018.

SCHILLEBEECKX, E. Revelação e teologia. São Paulo: Paulinas, 1968.

SENA DA SILVEIRA, E. (Org.). Como estudar as Religiões. Metodologias e estratégias. Petrópolis: Vozes, 2018.

SOUZA, W. "O Princípio responsabilidade" em Hans Jonas. Um desafio para a bioética numa contínua transcendência. Atualidade Teológica, v.14, n.35, p. 172-191, mai./ago. 2010. Disponível em: <https://www.maxwell.vrac.pucrio.br/17688/17688.PDFXXvmi=>. Acesso em: 30 de dez. 2018. 
TEPEDINO, A. M. (Org.). Memória, Identidade, Missão. Teologia da PUCRio - 45 anos. Rio de Janeiro: Editora PUC-Rio, 2013.

TEPEDINO, A. M. Uma identidade dinâmica. Buscando novas compreensões. In: TEPEDINO, A. M. (Org.). Memória, Identidade, Missão. Teologia da PUC-Rio - 45 anos. Rio de Janeiro: Editora PUC-Rio, 2013. p. 77-86.

TEPEDINO, A. M. Paz: dom messiânico e bem comum. In: PORTELLA AMADO, J.; AGOSTINI FERNANDES, L. (Orgs.). Cultura da Paz num mundo em conflito. Rio de Janeiro: Editora Puc-Rio / Letra Capital, 2017. p. 185-196.

TURKSON, P. Elementos constitutivos para uma sociedade mais justa e pacífica. In: PORTELLA AMADO, J.; AGOSTINI FERNANDES, L. (Orgs.). Cultura da Paz num mundo em conflito. Rio de Janeiro: Editora Puc-Rio / Letra Capital, 2017. p. 17-38.

VOLGRIMLER, H. Karl Rahner. Experiência de Deus em sua vida e em seu pensamento. São Paulo: Paulinas, 2006.

Abimar Oliveira de Moraes

Doutor em Teologia pela Università Pontificia Salesiana de Roma Docente do Departamento de Teologia da Pontifícia Universidade Católica do Rio de Janeiro Presidente do Conselho Diretor da Associação Nacional de Pós-graduação e Pesquisa em Teologia e Ciências da Religião Rio de Janeiro / RJ - Brasil E-mail: abimar@puc-rio.br

Recebido em: 18/10/18 Aprovado em: 08/03/19 